\title{
Managers' Perceptions of the Performance Appraisal System in the Local Municipality of Gauteng Province in South Africa
}

\author{
Dr. P. Q. Radebe \\ Department of Human Resources Management, Vaal University of Technology, \\ Vanderbijpark, Republic of South Africa \\ patrick@vut.ac.za
}

\section{Doi:10.5901/mjss.2015.v6n1s1p175}

\section{Abstract}

Performance appraisal is a critical component of the business process of performance management. In countries where performance appraisal was effectively implemented by municipalities there had been effective and efficient delivery of services. The pressure by government and service delivery protests in South Africa engenders the prioritisation of performance appraisal to meet service delivery mandates or targets. In light of the aforementioned pressures placed on municipalities the aim in this study was to evaluate managers' perceptions of the extent to which performance appraisal was effectively implemented in the local municipality of Gauteng Province. The research approach adopted in the study was line with the one applied by Lawler (1984). A survey research using structured questionnaire was used. Questionnaires were distributed to 94 pairs of managersubordinates (senior, middle and lower managers). As a follow-up to gaps that existed in the questionnaire feedback structured interviews were conducted with human resources manager and the line manager. The results of the study revealed that managers believed that performance appraisal system was not effectively implemented because there was no mutual setting of performance criteria and objectives. The performance appraisal system was also not linked to pay, promotion and manpower planning; it was also not geared towards career development of employees, and there was no climate of open communication and trust in the design and implementation of performance appraisal.

Keywords: performance appraisal system; performance management; pay-for-performance; performance measures.

\section{Introduction}

In South Africa, and some countries in the world, there is a mounting pressure from governments on municipalities to provide effective and efficient services. Coupled with the aforementioned pressure are the ever increasing community expectations for effective service delivery (Maila, 2006). In response to the pressure placed on them, municipalities in South Africa have put great focus on performance appraisal because it is believed that it is instrumental in improving performance and development of employees, thus impacting service delivery positively. As a result, public organisations, like the one under study, have begun to re-assess their performance evaluation systems. The information gleaned from an effective performance evaluation system could be used to assist the municipality to accomplish its mission. An effective performance appraisal system could also provide feedback to the municipality about whether the other human resources (HR) management functions are working in collaboration to execute the municipality's mission of service delivery(Jansen, 2003). An effective performance appraisal system is a tool through which municipalities can improve the productivity, quality, timeliness, responsiveness, and effectiveness of the service delivery programmes (Faizal, 2005). Notwithstanding the much lauded benefits of performance appraisal system, the manner in which it is developed and implemented in some organisations is often flawed. Against this backdrop it is not surprising to find that performance appraisal, in some municipalities, is not effectively developed and implemented, and in some cases non-existent (Hindo, 2010).

\section{Literature Review}

\subsection{Performance appraisal process}

The concepts of performance management and performance appraisal should not be used interchangeably as they are not similar. Performance management involves the process of planning, reviewing, rewarding and developing performance. It is an approach that creates a shared vision of the purpose and aims of the organisation, helping each 
individual employee understand and recognise their part in contributing to them and, in so doing, manage and enhance the performance of individuals and the organisation (Jackson \& Schuler, 2000). On the other hand, performance appraisal is a formal process, normally conducted by means of completing an instrument that identifies and documents a jobholder's contributions and workplace behaviours (Henderson, 2000). In other words, performance appraisal involves the systematic evaluation of individuals' performance. From the description of performance management, "reviewing" has been mentioned as one activity of performance management. "Reviewing" is a performance appraisal process. This means that performance appraisal is an integral component of performance management. While performance appraisal concerns itself only with extracting performance appraisal data, performance management utilises the extracted appraisal data for organisational planning efforts. Furthermore, performance management utilises appraisal data for developing and rewarding employees' performance (Bussin, 2002). This study confines itself to the performance appraisal process. Performance appraisal process should depart with establishing a performance agreement with employees. In essence, performance agreement entails the formulation of performance goals. Once general goals have been identified, the best practice would be to tailor them down to more specific objectives and standards required for day-to-day operations. Performance agreement should tacitly spell out the performance measures and key performance indicators together with competencies required to achieve them. Corporate values that should govern employee behaviour should also be stated in the performance agreement (Abraham, Karns, Shaw \& Mena, 2001). According to Maley (2013), performance appraisal serves two different objectives, namely, work or operational objectives and developmental objectives. Work objectives simply refer to the results to be achieved or the contribution to be made to the accomplishment of team, departmental and corporate objectives: they are job-related. The developmental objectives connote personal or learning objectives that are concerned with what individuals should do and learn to improve their performance or their knowledge, skills and competencies. The objectives should be mutually agreed upon between managers and subordinates. Previous study has indicated that compatibility between the boss and the subordinates based on the same objectives can have a significant impact on performance appraisal. Through joint objective setting appraisees develop a feeling of ownership, which has a more powerful effect upon subsequent performance than just a general discussion about goals (Prowse \& Prowse, 2009). Objectives setting allows employees to know up-front the standards by which their performance will be evaluated. Pettijohn, Parker, Pettijohn and Kent (2001) hint that the activity of setting performance objectives should be characterised by effective communication for parties in the performance appraisal process to have a common understanding of performance expectations. Performance measures are pivotal yardsticks for attainment of performance objectives. The saying that "if you can't measure it, you can't improve it" serves to explain that there is a need to agree and develop a common understanding on how the performance objectives or standards will be measured. Otherwise it is pointless defining objectives or performance standards without indicating measures for their achievement. To this end, performance measures should provide evidence of whether or not the intended results have been achieved and the extent to which the jobholder has produced the results. This will be the basis for generating feedback information for use not only by managers, but also by individuals, to monitor their own performance (Piggot-Irvine, 2003). An effective performance appraisal system requires that employees' roles and responsibilities be clarified beforehand so that it could be explained how the roles and responsibilities contribute to wider team or organisational goals. This practice creates linkages between individual employee performance with organisational goals without which, entropy and not synergy, becomes the order of the day (Tuytens \& Devos, 2012). According to Robbins (2001), supervisors, peers, self or others, depending on the organisation, can conduct a performance review. Alternatively, some organisations have come to rely on a 360 degree performance appraisal where supervisors, self, peer and customer reviews are used together to appraise the performance of an employee. A variety of appraisal techniques are used in conducting performance appraisal. These include, inter alia, graphic rating scales, non-graphic rating scales, ranking, forced distribution and paired comparison. After the performance of the employee has been measured using the aforementioned mechanisms, it is imperative for managers to hold appraisal interviews with appraises to discuss appraisal feedback.

\subsection{The significance of performance appraisal system}

The value of performance appraisal lies in providing feedback to subordinates about their performance so that they know their strengths and weaknesses. Knowledge of weak performance areas provides managers with the opportunity to develop improvement plans geared towards enhancing performance. In a way, using a performance appraisal system provides management with the means of warning subordinates about unsatisfactory performance. In as much as the performance appraisal system assists in enhancing employee performance it is an instrument that can be used for the evaluation of training programmes (Kuvaas, 2011). Employees can further benefit from the use of performance appraisal in the sense that appraisal data can be utilised to identify career opportunities and map out their career planning, thus 
increasing employees' commitment to the organisation. Needless to say, career planning efforts imbue employees with motivation when they realise that they are recognised and supported. The additional spinoff of career planning efforts is the strengthening of manager and subordinate relations (Rowland \& Hall, 2013). There is a common contention that performance appraisal facilitates pay and promotion decisions, especially in organisations where pay-for-performance is practiced and where promotion is based on performance. Performance appraisal system can also be used to help management in making termination and retention decisions (Rowland \& Hall, 2012).

\subsection{Problems and errors involved in performance appraisal}

There is ambivalence on appraisers' and appraisees' sides to participate in the performance appraisal process. Superiors are uncomfortable because their organisational role places them in an invidious position of being a judge and a jury to make decisions that affect people's careers and lives. Most managers are not trained to handle difficult interpersonal situations that are likely to arise when feedback is negative. They also want to maintain good relations with subordinates. At the same time, subordinates are likely to be very ambivalent about receiving negative feedback. They are likely to want to discuss negative aspects of their performance so they can improve and develop, but would not want to jeopardise promotions, pay or their own self-image (Greguras, Ford \& Brutus, 2003). Receiving negative feedback may elicit resistance from subordinates. To exacerbate problems, subordinates may try to blame others for uncontrollable events or for their unsatisfactory performance. They may go as far as questioning the performance appraisal system or minimise its importance; they can demean the source of data; apologise and promise to do better in the hope of shortening their exposure to negative feedback; and they can agree too readily to the feedback while inwardly denying its validity or accuracy. Defensiveness leads to open hostility and denials. Subordinates may become passive and exhibit surface compliance (Jackson \& Schuler, 2000). According to Mathis and Jackson (2000), the typical employee's job is made of a number of tasks. If performance on a job were to be assessed by a single criterion measure the result would be a limited evaluation of this aforementioned job. If employees were evaluated on a single criterion, they would emphasise the single criterion to the detriment, or even exclusion, of other relevant job criteria although it is quite clear that successful performance of the job depends on these criteria. Robbins (2001) adds that there is also the problem of managers using different standards and expectations for employees performing similar jobs. This is bound to elicit anger from employees. Such problems are likely to exist when ambiguous criteria and subjective weightings by supervisors are used. In implementing performance appraisal, raters tend to make errors. There is a tendency for raters to be lenient or strict when giving ratings to ratees. In the former case, the rater overstates the performance of a ratee, that is, a ratee is rated higher than his/her actual performance. In the latter situation, the performance of a ratee is understated. A rate is given lower ratings than what he/she really deserves (Simmons, 2002). A recency error occurs when performance appraisal is based on the employee's recent behaviour, good or bad. The resulting performance review will be biased either favourably or unfavourably, depending on the way the performance information is selected, evaluated, and organised by the rater. Without work record or documentation for the entire appraisal period, the rater is forced to recall recent employee behaviour to establish the rating (Appelbaum, Roy \& Gilliland, 2011). Cook and Crossman (2004) consider central tendency as a performance appraisal situation in which a rater tends to rate employees as average performers, thus becoming reluctant to give very good or very bad ratings. As such the ratings fail to discriminate either within or between people.

Ratees' performance is considered to be the same irrespective of the different actual effort they exert. The halo effect is when a rater lets one particular aspect of an employee's performance influences the evaluation of other aspects of performance. Basically, a rater assigns ratings on the basis of a global impression of a ratee. In this case, a rater fails to distinguish among levels of performance on different performance dimensions. Conversely, a negative halo or devil's horns effect exists when the employee's ratings on all other dimensions is lowered inaccurately due to an accurate poor rating on one dimension (Grobler, Warnich, Carrel, Elbert \& Hatfield, 2011).

\section{The Purpose of the Study}

The purpose of the study was to evaluate managers' perceptions of the extent to which performance appraisal system was effectively implemented in the local municipality of the Gauteng Province in South Africa. 


\section{Research Methodology}

\subsection{Population and Sample}

The population from which the sample was selected consisted of 226 managers made up as follows: 26 senior managers, 70 middle managers, and 130 pairs junior managers. The sample was constituted as follows: all 26 senior managers were part of the study; $50 \%$ (35) middle managers and $25 \%$ (33) junior managers. The managers were paired with subordinates resulting into 94 pairs of manager-subordinates. The total sample of 94 pairs could not be selected randomly as it was essential to sample manager-subordinate pairs. The researcher was actively involved in deciding who formed part of the study to ensure that these pairs existed in practice. It actually occurred that the one who was an appraiser could also be an appraisee. Respondents' names appeared on the questionnaire to ensure that identifiable pairs existed. However, confidentiality was maintained because the contents of the completed questionnaires were not discussed with any of the respondents. The researcher determined that a good response rate would be 80 pairs of completed and returned questionnaires, making up $85 \%$ response rate.

\subsection{Instrumentation}

The questionnaire was given to pairs of top, middle and junior management. It happened that the person being appraised was also responsible for appraising the performance of others. As a result he/she had to answer the same questions: first as the appraiser and, second, as the appraisee. Because of the enormity of filling the questionnaire, first as an appraiser and second as an appraisee, the three-Likert scale questionnaire was utilised with "Agree", "Neutral" and "Disagree"scales. The questionnaire constituted of statements pertaining to performance agreement, administrative decisions and managers' experiences of performance appraisal. Structured interviews were conducted with the human resource manager and the line manager. Interview proceedings were not recorded. Comprehensive notes were made during the interview and transcribed immediately afterwards to avoid loss of clarity. The interview-guide was developed once the results of the questionnaire were known in order to clarify existing gaps in the questionnaire feedback.

\subsection{Analysis of data}

Data obtained from the questionnaires was computed using the Statistical Package for Social Sciences (SPSS) version 21.0 of Windows. Frequency analysis was performed.

Percentage variations were calculated to determine the degree of agreeableness or otherwise between managerssubordinate pairs. Percentage variation in the responses above $15 \%$ was deemed "meaningful" to give cause for concern and required further probing through structured interviews with the human resource manager and the line manager.

In contrast, $0 \%$ to $15 \%$ variation in the responses was considered as "not meaningful", implying that respondents held a somewhat similar perception.

\subsection{Reliability and validity}

To enhance the reliability and validity of the research instruments contradicting evidence was clarified with the human resource manager and the line manager. The relevance of the questionnaire statements was validated through expert opinions from academics. Respondent validation was also pursued by referring the analysis of the interview results back to the interviewees for them to confirm the researcher's conclusions. Before embarking on the collection of data, the questionnaire was pilot-tested on a group of employees from different management levels. The questionnaire was refined prior to being administered to respondents.

\section{Results}

\subsection{Response rate}

There was a total sample of 94 pairs of appraisers and appraisees (manager-subordinate pairs) that formed the sample. Pairing respondents on the basis of biographical criteria was impossible and could lead to a small sample size if performed, thereby jeopardising the representativeness of sampled respondents in the study. For this reason, it was considered appropriate not to conduct the description of biographical information in this section. Nonetheless, a good 
response rate was deemed to be 80 pairs of completed and returned questionnaires, representing an $85 \%$ response rate. The researcher was able to retrieve 83 pairs of questionnaires from respondents thereby attaining a sufficient $88 \%$ response rate.

\subsection{Empirical analysis}

The results in table 1 show that a higher percentage of appraisers (57\%) disagrees with the questionnaire statement, "management and subordinates identify objectives well before the performance period" while a lower percentage (30\%) of appraisees disagrees with the questionnaire statement.

It can be observed from table 1 that 33\% of appraises and 23\% appraisers agree with the questionnaire statement. For the questionnaire statement, "performance appraisal is based on general agreement on performance criteria (what is measured)", appraisers' and appraisees' responses are $20 \%$ and $34 \%$ respectively in the "Agree" scale; and $63 \%$ and $43 \%$ in the "Disagree" scale. Table 1 shows that there is a great percentage variation in the "disagree" scale (27\% and $20 \%)$ for both questionnaire statements. Notwithstanding the percentage variation, a higher percentage of appraisers disagreeing with the questionnaire statement led to the conclusion that management and subordinates do not identify objectives before the performance period.

Table 1: Responses in respect of performance agreement and measures

\begin{tabular}{|l|c|c|c|c|c|}
\hline Questionnaire statements & Respondents & Agree & $\begin{array}{c}\text { \% Variation on } \\
\text { Agree }\end{array}$ & Disagree & $\begin{array}{c}\text { \% Variation on } \\
\text { Disagree }\end{array}$ \\
\hline $\begin{array}{l}\text { Management and subordinates identify objectives well before } \\
\text { the performance period }\end{array}$ & Appraisers & $23 \%$ & $10 \%$ & $57 \%$ & $27 \%$ \\
\hline $\begin{array}{l}\text { Performance appraisal is based on general agreement on } \\
\text { performance criteria (what is measured) }\end{array}$ & $\begin{array}{c}\text { Appraisers } \\
\text { peraiseess }\end{array}$ & $\begin{array}{l}20 \% \\
34 \%\end{array}$ & $14 \%$ & $63 \%$ & $20 \%$ \\
\hline
\end{tabular}

The conclusion is deemed valid because the appraisers by virtue of their position in the performance appraisal process should know more about its objectives than appraisees. This is in contrast to the accepted good practice that an effective performance appraisal system is one characterised by mutual setting of objectives and contracting on performance measures before the performance period (Kuvaas, 2011). Nonetheless, a follow-up structured interview with the human resource manager and the line manager was conducted to shed light on the high percentage variation for the questionnaire statements. The human resource manager's observation was that subordinates' performance of duties was based on their acquired experience. According to the line manager, meetings for identification of performance objectives were seldom held. The line manager observed that "management only enters the picture when things go wrong". Otherwise, both management and subordinates have sporadic and informal discussions about work in general. From this it could be concluded that management and subordinates did not meet formally to identify objectives well before the performance period. Previous research indicates that without performance objectives, the daily activities of managers will lack direction. It would seem that senior managers have knowledge of what needs to be accomplished monthly but fail in their duty to jointly set the objectives with managers in the lower rung of the local municipality's ladder. Poor communication on the part of senior managers leads to poor performance planning which will translate into an ineffective performance appraisal (Maley, 2013). From the results in table 1 it could also be safely maintained that the performance appraisal system is not based on performance criteria or measures. If managers and subordinates seldom meet to identify performance objectives it is hard to imagine how they could agree on what should be measured. Both the line manager and the human resource manager agreed that there was a possibility that managers and subordinates were not meeting to agree on performance measures. The human resource manager had previously reported that objectives set with senior managers were not cascaded down to middle and junior managers. This situation does not offer opportunities for the identification and discussion of performance measures. Previous research indicates that there is a dire need to agree on and develop common understanding of how attainment of performance will be measured. Performance measures serve to provide information on the extent to which intended results have been achieved and the extent to which the jobholder has produced results (Khoury \& Analoui, 2004). Table 2 illustrates questionnaire statements that were anchored on administrative decisions such as pay, promotion, manpower planning as well as job responsibilities and duties. In table 2 a substantial percentage of appraisers (86 \%) and appraisees (79\%) disagree with the questionnaire statement, "performance appraisal is linked to pay" with a small percentage variation of $7 \%$ for both "Agree" and "Disagree" scales. As a result of the low percentage variation both appraisers and appraises could be considered to 
hold similar view in respect of the aforementioned questionnaire statement.

Table 2: Responses in respect of administrative decisions

\begin{tabular}{|c|c|c|c|c|c|}
\hline Questionnaire statements & Respondents & Agree & $\begin{array}{l}\% \text { Variation } \\
\text { on Agree }\end{array}$ & Disagree & $\begin{array}{l}\text { \% Variation on } \\
\text { Disagree }\end{array}$ \\
\hline Performance appraisal is linked to pay & $\begin{array}{l}\text { Appraisers } \\
\text { Appraisees }\end{array}$ & $\begin{array}{c}10 \% \\
7 \%\end{array}$ & $7 \%$ & $\begin{array}{l}86 \% \\
79 \%\end{array}$ & $7 \%$ \\
\hline Performance appraisal is linked to promotion & $\begin{array}{l}\text { Appraisers } \\
\text { Appraisees }\end{array}$ & $\begin{array}{l}11 \% \\
25 \%\end{array}$ & $14 \%$ & $\begin{array}{l}79 \% \\
65 \%\end{array}$ & $14 \%$ \\
\hline Performance appraisal is linked to manpower planning & $\begin{array}{l}\text { Appraisers } \\
\text { Appraisees }\end{array}$ & $\begin{array}{ll}10 \% \\
20 \%\end{array}$ & $10 \%$ & $\begin{array}{l}67 \% \\
60 \%\end{array}$ & $7 \%$ \\
\hline $\begin{array}{l}\text { Performance appraisal is linked to job responsibilities and } \\
\text { duties }\end{array}$ & $\begin{array}{l}\text { Appraisers } \\
\text { Appraisees }\end{array}$ & $\begin{array}{l}37 \% \\
37 \%\end{array}$ & $0 \%$ & $\begin{array}{l}43 \% \\
40 \% \\
\end{array}$ & $3 \%$ \\
\hline $\begin{array}{l}\text { Management's and subordinates' jobs are clearly specified } \\
\text { and well defined }\end{array}$ & $\begin{array}{l}\text { Appraisers } \\
\text { Appraisees }\end{array}$ & $\begin{array}{l}3 \% \\
5 \%\end{array}$ & $20 \%$ & $\begin{array}{l}60 \% \\
40 \%\end{array}$ & $20 \%$ \\
\hline
\end{tabular}

The results led to an acceptance of the finding that performance appraisal is not linked to pay in the local municipality. Pay is based on seniority and tenure in the job. Evidence from previous research suggests that an effective performance appraisal is one that yields performance appraisal data that should be utilised to pay employees. Pay that is related to performance motivates employees to perform better. It is also important that decisions about pay related to performance appraisal be communicated to employees (Turk, 2008). Table 2 further illustrates that a significantly higher percentage of appraisers $(79 \%)$ and appraisees $(65 \%)$ disagree with questionnaire statement, "performance appraisal is linked to promotion". The percentage variation for this statement $(14 \%)$ is "not meaningful", hence the assertion that both appraisers and appraisees hold a similar view with regard to this questionnaire statement. The finding is, therefore, that performance appraisal in the local municipality is not linked to promotion. As in the case of pay, promotion is based on the level of experience in the job, that is, good performance in a job does not guarantee promotion. Conversely, Schyns (2006) suggests that an effective performance appraisal is typically one that is linked to promotion. Put differently, employees' promotion should be contingent upon their performance and potential. Table 2 highlights that both appraisers $(67 \%)$ and appraisees (60\%) disagree with questionnaire statement, "performance appraisal is linked to manpower planning". A low percentage of appraisers (10\%) and appraisees (20\%) agree with the questionnaire statement with a low percentage variation of $10 \%$ for "Agree" and $7 \%$ for "Disagree" scales. Emerging from the results is that performance appraisal is not linked to manpower planning in the local municipality. It is evident that an equal percentage (37\%) of appraisers and appraisees agree that "performance appraisal is linked to job responsibilities and duties". In contrast, 43\% of appraisers and $40 \%$ appraisees disagree with the questionnaire statement. The percentage variations for both the "Agree" and the "Disagree" scales are very low (nil and $3 \%$ respectively).

Thus, both appraisers and appraisees could be deemed to hold a similar view in this respect; hence the revelation that performance appraisal is not linked to job responsibilities and duties in the municipality under study.

For the questionnaire statement, "management's and subordinates' job responsibilities and duties are clearly specified and clearly defined", $60 \%$ and $40 \%$ of appraisers and appraises respectively, disagree with the questionnaire statement. Apparent from the empirical data is that the job responsibilities and duties are not clearly specified and clearly defined in the demarcated area of study. Tuytens and Devos (2012) propose that employees' roles and responsibilities should be properly identified after which they should be used as a predication against which their performance will be appraised. To enhance the effectiveness of the performance appraisal, employees' roles and responsibilities should be clearly specified and defined.

Table 3: Reponses in respect of managers' experiences of s appraisal

\begin{tabular}{|l|c|c|c|c|c|}
\hline Questionnaire statements & Respondents & Agree & $\begin{array}{c}\text { \% Variation on } \\
\text { Agree }\end{array}$ & Disagree & $\begin{array}{c}\text { \% Variation on } \\
\text { Disagree }\end{array}$ \\
\hline $\begin{array}{l}\text { Performance appraisal is done for subordinates' career } \\
\text { development }\end{array}$ & $\begin{array}{c}\text { Appraisers } \\
\text { Appraisees }\end{array}$ & $26 \%$ & $6 \%$ & $67 \%$ & $0 \%$ \\
\hline $\begin{array}{l}\text { There is open communication as to the design and } \\
\text { implementation of performance appraisal }\end{array}$ & $\begin{array}{c}\text { Appraisers } \\
\text { Appraisees }\end{array}$ & $\begin{array}{l}20 \% \\
34 \%\end{array}$ & $14 \%$ & $63 \%$ & $20 \%$ \\
\hline There is a climate of trust, support and openness between & Appraisers & $36 \%$ & $16 \%$ & $70 \%$ & $20 \%$ \\
\hline appraisers and appraises & Appraisees & $20 \%$ & $60 \%$ & $10 \%$ \\
\hline
\end{tabular}


Table 3 indicates that both appraisers (67\%) and appraisees (67\%) disagree with the questionnaire statement, "performance appraisal is done for subordinates' career development". The percentage variation for this statement is zero, implying that both appraisers and appraisees hold a similar view. It could be concluded that performance appraisal is not geared towards career development of employees. Employees who consider performance appraisal as a tool implemented to shape their career paths are more prone to allow its implementation and accept performance results (Cook \& Crossman, 2014). The responses to the questionnaire statement, "there is open communication as to the design and implementation of performance appraisal" were negative, with both appraisers (63\%) and appraises (43\%) disagreeing with the questionnaire statement. The variation of $20 \%$ was recorded for the responses. To seek more clarity the line manager was interviewed who confirmed that there was no consultation between managers and subordinates about the development of performance appraisal. The subordinates did not co-operate with managers because the subordinates feared that the system of performance appraisal could jeopardise their employment. When performance appraisal was conducted or implemented it was devoid of mutual trust, openness and supportiveness. The human resource manager concurred with the view that there is little consultation, if any, with subordinates on developing performance appraisal. Indeed, performance appraisal was an imposed process. In other words, it was a model that had been developed by the South African Local Government Association (SALGA). Simmons (2002) suggests that managers and subordinates should be equally involved in the development of a performance appraisal system. The spin-off for encouraging subordinates' inputs is mutual understanding between managers and subordinates.

An improved manager-subordinate relationship lays down a foundation of trust and supportiveness in discussion of performance problems. With regard to the questionnaire statement: "there is a climate of trust, support and openness between appraisers and appraisees", $70 \%$ of appraisers and $63 \%$ of appraisees disagreed with the questionnaire statement. The variation for responses was $13 \%$ thereby making the variation "not meaningful". The conclusion from these results is that performance appraisal is not characterised by a climate of trust, support and openness between appraisers and appraisees. It has already been alluded earlier that lack of trust, support and openness between appraisers and appraises negatively affect the implementation of a performance appraisal system.

\section{Limitations}

The findings of the research cannot be generalised to other municipalities because the sample was not drawn randomly. The researcher did not opt for a random selection of the sample because he had to ensure that manager-subordinate pairs existed practically. As a result, not every manager-subordinate pair had an equal chance of being selected. Nonetheless, the findings in the local municipality could serve as pointers of potential problems of performance problems in other municipalities. Another limitation of the study was that it focused on performance appraisal, a subcomponent performance management, and not on performance management as a whole.

\section{Recommendations}

The formal implementation of performance appraisal would necessitate formal performance meetings wherein both management and subordinates identify performance objectives and criteria as yardsticks of performance appraisal. In addition, it would be advantageous for management to use the job descriptions that employees signed at the time of commencing their employment with the local municipality. This could serve as a basis for identifying performance objectives and criteria. The practice of providing job descriptions would extend to helping employees understand their roles and responsibilities. In this way overlapping of jobs might be avoided. During the performance appraisal meetings, management should allow subordinates to make inputs about performance objectives and criteria to avoid imposition of performance objectives and measures.

\section{Suggestions for Further Research}

The current research investigated management's perception of the effective implementation of performance appraisal in the local municipality. Further research could explore the perception of ordinary employees about the effectiveness with which performance appraisal is implemented in the same local municipality. The research could be extended to include sampled local municipalities in South Africa to probe what the picture would be like if all local municipalities had an equal chance of being selected. The present research focused on management's perception of performance appraisal at one point in time, in other words a "snapshot" view. Another possible area of research could be to undertake a longitudinal study of performance appraisal. The managers' perceptions of performance appraisal could be measured before, during 
and after the implementation of this process over a five-year period. This extended research would measure empirically whether benefits that are supposed to accompany an effective implementation of performance appraisal are actually realised.

\section{Conclusion}

The general contention emanating from the study is that performance appraisal is not effectively implemented in the local municipality. It is apparent from the findings that management and subordinates do not meet to identify performance objectives and criteria before the performance period. If they do meet such meetings are of an informal nature. Performance appraisal, as practised in the local municipality, is not linked to pay and promotion. Experience and the level of seniority in the organisation serve as the bases for remuneration and promotion. Furthermore, in the local municipality, performance appraisal is not linked to manpower planning and there is no open communication in the design and in the implementation of performance appraisal. The climate of trust between management and subordinates is non-existent.

\section{References}

Abraham, S.E., Karns, L.A., Shaw, K. \& Mena, M.A. (2001). Managerial Competencies and the Managerial Performance Appraisal Process. The Journal of Management Development, 20(10), 842-852. Appelbaum, S.H., Roy, M. \& Gilliland, T. (2011). Globalization of performance appraisals: theory and applications. Management Decision, 49(4), 570-585.

Bussin, M. (2002). Pay for Performance. Johannesburg: Wits Business School (University of the Witwatersrand).

Cook, J. \& Crossman, A. (2004). Satisfaction with performance appraisal systems: A study of role perceptions. Journal of Managerial Psychology, 19(5),526-541. Faizal, M. (2005). Institutionalization of performance appraisal system: A case study of the Maldivian Public Service. Norway: University of Bergen.

Greguras, G., Ford, J.M. \& Brutus, S. (2003). Manager Attention to Multisource Feedback. The Journal of Management Development, 22(4), 345-361. Grobler, P.A., Warnich, S., Carrel, M.R., Elbert, F.E. \& Hatfield, R.D. (2011). Human Resource Management in South Africa. Hampshire: Cengage Learning. Henderson, R.I. (2000). Compensation Management in a Knowledge-Based World. (8thed). New Jersey: Prentice Hall. Hindo, S. (2010). Utilization of performance appraisal in local governments: Extent and Challenges.Wayne State: Wayne State University Dissertations.

Jackson, S.E. \& Schuler, R.S. (2000). Managing Human Resources. Boston: South-Western College Publishing.

Jansen, D.E.F. (2003). A proposed performance management system for the greater Stellenbosch municipality. Stellenbosch: Cape Peninsula University of Technology.

Khoury, G.C. \& Analoui, F. (2004). Innovative Management Model for Performance Appraisal: The Case of Palestinian Public Universities. Management Research News, 27 (1), 56-74.

Kuvass, B. (2011). The interactive role of performance appraisal reactions and regular feedback. Journal of Managerial Psychology, 26 (2), 123-137.

Lawler, E.E., Mohrman, A.M. Jnr \& Resnick, S.M. (1984). Performance Appraisal Revisited. Organisational Dynamics, March-April, 20-35.

Maila, H. (2006). Performance management and service delivery in the Department of Water Affairs and Forestry. Pretoria: University of South Africa. Maley, J. (2013). Hybrid purposes of performance appraisal in a crisis. Journal of Management Development, 32 (10), 1093-1112.

Mathis, R.L. \& Jackson, J.H. (2000). Human Resources Management. Boston: South-WesternCollege Publishing.

Pettijohn, L.S., Parker, R.S., Pettijohn, C.E. \& Kent, O.L. (2001). Performance Appraisal: Usage, Criteria and Observations. The Journal of Management Development, 20 (9), 754-771. Piggot

Irvine, (2003). Key features of appraisal effectiveness. International Journal of Educational Management, 17(4), 170-178.

Prowse, P. \& Prowse, J. (2009). The dilemma of performance appraisal. Measuring Business Excellence, 13(4), 69-77.

Robbins, S.P. (2001). Organisational Behaviour (9th ed). New Jersey: Prentice Hall.

Rowland, C.A. \& Hall, R.D. (2012). Organisational justice and performance: is appraisal fair? EuroMed Journal of Business, 7(3), 280293. Rowland, C.A. \& Hall, R.D. (2013). Perceived unfairness in appraisal: engagement and sustainable organizational performance, EuroMed Journal of Business, 8 (3), 195-208.

Simmons, J. (2002). An "Expert Witness" Perspective on Performance Appraisal in Universities and Colleges. Employee Relations, 24(1) , 86-100.

Schyns, B. (2006). The role of implicit leadership theories in the performance appraisals and promotion recommendations of leaders. Equal Opportunities International, 25 (3), 188-199.

Turk, K. 2008. Performance appraisal and the compensation of academic staff in the University of Tartu, 3 (1), 40-54.

Tuytens, M. \& Devos, G. (2012). Importance of system and leadership in performance appraisal. Personnel Review, 41(6), 756-776. 